\title{
Pre-clinical evaluation of the treatment with MSCs of fistular pathology in inflammatory bowel diseases
}

Luis Mariñas-Pardo*, Laura Núñez-Naveira and Manuel Hermida-Prieto

Centauri Biotech, S.L., C/ Asunción s/n, 1º Izq, 15142, Meicende - Arteixo, A Coruña, Spain

\section{Introduction}

Perianal disease includes the presence of fistulas, abscesses, fissures and stenoses that place a burden on the patient due to perianal losses, pain and a decrease in quality of life. It is a disease in which the body produces an immune reaction against itself. The traditional treatment of this pathology includes the use of antibiotics and immunomodulatory drugs or surgery. However, surgery may not always be performed due to the inherent risk of the procedure or the incontinence sequelae it may cause.

Peri-anal fistulas can affect both dogs [1] and cats, becoming perfect animal models of spontaneous (non-induced) disease. Their presence is much less frequent in felines [2], but their symptoms are analogous to those observed in human pathology. Clinical signs, histopathology, cytokine profile of the lesion, and response to cyclosporine therapy are similar to those seen in humans.

Mesenchymal stem cells (MSCs) have been shown to have immunomodulatory potency and their use for the treatment of perianal fistulas in humans has shown promising results [3]. Most of the treatments studied were based on the autologous use of MSCs demonstrating their efficacy [4]. However, the use of allogeneic MSCs in humans has also been successful in healing perianal fistulas in patients with Crohn's disease who do not respond to conventional treatments [5]. In fact, Darvadstrocel, the first allogeneic mesenchymal stem cell-based drug for the treatment of this condition, was approved for marketing in 2017 [6]. Although there is nothing published on the use of MSCs for the treatment of fistulas in cats, a positive response to the treatment of canines with MSCs of human origin has been described [7].

Considering the above, the use of MSCs in cats could mimic the human disease. The aim of this work was to test the efficacy and safety of MSCs treatment of feline perianal fistulas, trying to validate an animal model of spontaneous disease.

\section{Material and methods}

All animal procedures and protocols were performed by licensed veterinarians and complied with national and European legislation (Spanish Royal Decree RD1201/2005 and EU Directive 86/609/EEC amended by $2003 / 65 / \mathrm{EC}$, respectively) for the protection of animals used for research experimentation and other scientific purposes.

The patient was a male cat of 6 years old and weighing $4.2 \mathrm{~kg}$. It had signs of perianal fistula with two fistulous pathways. As a result of an antibiotherapy analysis, it was incompatible with corticoids and immunosuppressants. Surgery and laser therapy were performed with poor results.

Mesenchymal stem cells were obtained from adipose tissue after surgery and were processed and characterized following protocols described above [8]. Briefly, the adipose tissue was digested with collagenase at $37^{\circ} \mathrm{C}$ and the vascular fraction obtained was cultured with DMEM enriched with $10 \%$ FBS and $1 \%$ glutamine-penicillinstreptomycin. When the culture confluence exceeded $75 \%$, the cells dissociated and expanded repeatedly to three or four. The cells were resuspended in an excipient, loaded into syringes and sent for treatment of ferrets at room temperature.

The cat received 2 doses of $3.8 \times 106$ cells on day 0 (D0) and was clinically evaluated on days D15, D45, D90 and D150.

\section{Results}

Local treatment of MSC in the fistula trajectory was well tolerated, with no significant adverse events. Fifteen days after the treatment with no other concomitant medicines, fistulas started to heal. At day 45 , the fistulas were almost completely closed, what happened at day 90 .

In the review performed 150 days after treatment, the results continued to be positive and the patient was discharged as disease was considered under control (Figure 1).

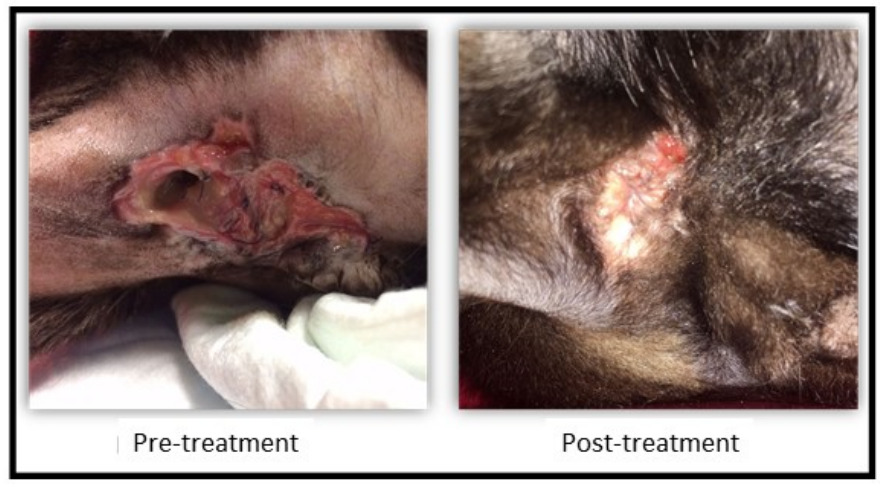

Figure 1. Treatment of MSC in the fistula trajectory

*Correspondence to: Luis Mariñas-Pardo, Centauri Biotech, S.L., C/ Asunción s/n, 1 Izq, 15142, Meicende - Arteixo, A Coruña, Spain, Tel: +34 881993 722; E-mail: luis.marinas@centauribiotech.com

Received: May 13, 2019; Accepted: May 27, 2019; Published: May 30, 2019 


\section{Conclusion}

This paper presents for the first time the use of feline mesenchymal stem cells as therapy for the treatment of perianal fistulas in cats. Although no data are presented from a control group (animals without cell treatment), spontaneous recovery of perianal fistulas is an extremely rare event and it is common to require lifelong treatment. The results demonstrate not only the efficacy of the treatment but also that it is a safe procedure without local or systemic adverse effects after cell implantation.

However, a study with a larger number of animals including a control group is necessary to confirm the results described in this paper and to determine the frequency of periodic injections needed to control the symptoms of the disease.

\section{References}

1. Houlton JE (2018) Anal furunculosis: a review of seventy cases. J Small Anim Pract 21: 575-584. [Crossref]
2. Scarff DH (2019) Anal sac diseases and perianal fistula. Companion Anim 21: 608-613.

3. Dailey FE, Turse EP, Naseer M, Bragg JD, Tahan V (2018) Review of stem cells as promising therapy for perianal disease in inflammatory bowel disease. World $J$ Transplant 8: 97-101. [Crossref]

4. Gold SL, Cohen-Mekelburg S, Schneider Y, Steinlauf A (2018) Perianal Fistulas in Patients With Crohn's Disease, Part 2: Surgical, Endoscopic, and Future Therapies. Gastroenterol Hepatol 14: 521-528. [Crossref]

5. Panés J, García-Olmo D, Van Assche G, Colombel JF, Reinisch W, et al. (2016) Expanded allogeneic adipose-derived mesenchymal stem cells (Cx601) for complex perianal fistulas in Crohn's disease: a phase 3 randomised, double-blind controlled trial. Lancet 388: 1281-1290. [Crossref]

6. Scott LJ (2018) Darvadstrocel: A Review in Treatment-Refractory Complex Perianal Fistulas in Crohn's Disease. BioDrugs 32: 627-634. [Crossref]

7. Ferrer L, Kimbrel EA, Lam A, Falk EB, Zewe C, et al. (2016) Treatment of perianal fistulas with human embryonic stem cell-derived mesenchymal stem cells: a canine model of human fistulizing Crohn's disease. Regen Med 11: 33-43.

8. Pérez-Merino EM, Usón-Casaús JM, Zaragoza-Bayle C, Duque-Carrasco J, MariñasPardo L, et al. (2015) Safety and efficacy of allogeneic adipose tissue-derived mesenchymal stem cells for treatment of dogs with inflammatory bowel disease: Clinical and laboratory outcomes. Vet J 206: 385-390. [Crossref]

Copyright: (C2019 Mariñas-Pardo L. This is an open-access article distributed under the terms of the Creative Commons Attribution License, which permits unrestricted use, distribution, and reproduction in any medium, provided the original author and source are credited. 